\title{
Mevlânâ Halidi Bağdâdî’den Günümüze Cizre’de Faaliyet Göstermiş Tarikatlar ve Temsilcileri
}

\section{Sects And Theır Representatıves That Have Been Actıved In Cizre From Mawlana Khalıd-ı Baghdadı To Current}

\author{
Mesut Yiğit ${ }^{\mathrm{a}, *}$ \\ ${ }^{a}$ Dr. Öğr. Üyesi, Muş Alparslan Üniversitesi İslami İlimler Fakültesi, Tasavvuf Anabilim Dalı, 49100, Muş/Türkiye. \\ ORCID: 0000-0002-9939-4235
}

\begin{tabular}{l} 
MAKALE BİLGİSİ \\
Makale Geçmişi: \\
Başvuru tarihi: 31 Ocak 2020 \\
Düzeltme tarihi: 20 Ekim 2020 \\
Kabul tarihi: 28 Ekim 2020 \\
\hline Anahtar Kelimeler: \\
Cizre \\
Kadiriyye \\
Nakşibendiyye \\
Rufaiyye.
\end{tabular}

\section{ARTICLE IN FO}

Article history:

Received 31 January 2020

Received in revised form 20 October 2020

Accepted 28 October 2020

Keywords:
Cizre
Qadiriyya
Naqshbandiyya
Rifa'iyya.

ÖZ

Tasavvuf tarihinde önemli bir konuma sahip olan Cizre, Mevlânâ Hâlid-i Bağdâdî'den sonra Nakşî-Hâlidî, Kâdirî ve Rufâî yolunun büyüklerinin yoğunlukla yetiştiği bir yerdir. İslam tarihinde ilim, kültür ve sanatta merkezi bir konumda olmasına rağmen Cizre'de yaşayan ve faaliyet gösteren mutasavvıflar hakkında sadra şifa bir araştırma yapılmamıştır. Yapılan bazı araştırmalar da genelde Mevlânâ Hâlid-i Bağdâdî'nin son halifelerinden, Cizre'nin önemli âlimlerinden olan Şeyh Hâlid-i Cezerî ve halifeleri ekseninde olduğu için kapsayıcı olamamıştır. Buna göre Cizre'de bulunan Mevlânâ Hâlid-i Bağdâdî’nin baş halifesi Şeyh Osman Siracüddin et-Tavîlî yoluna bağlı halifelerle Kâdirî ve Rufâî halifelerinin de hayatlarının incelenip ilim ve fikir dünyasına ulaştırılması elzem görülmektedir. $\mathrm{Bu}$ amaçla tasavvuf düşüncesinin yaşanıp geliştiği merkezlerden biri olan Cizre'nin mutasavvıflarının en azından belirli bir kısmını tanıtmanın temel hedefimiz olduğunu belirtmek isteriz.

\section{Giriş}

Tarihin kadim şehri Cizre pek çok uygarlığa ev sahipliği yapmış İslam medeniyetinin önemli ilim ve kültür merkezlerinden biridir. Hz. Ömer tarafindan el-Cezire ${ }^{1}$

1 el-Cezire Dicle ve Fırat nehirleri arasında olan geniş bir bölgenin adıdır. Yukarı Mezopotamya da denilen, günümüzde Türkiye, Suriye ve Irak'ta yer alan Malatya, Adıyaman, Diyarbakır, Mardin, Cizre, Re'sü'l-'ayn, Musul gibi mümbit şehirleri içermektedir. Bkz. (ŞEŞEN, 1993: 7/509). valisi olarak atanan sahabe İyaz b. Ganem (v. 20/641) komutasında fethedilmiştir. (Vâkıdî, 1417/1996: 234-235) Adını meşhur rivayete göre ilk defa bugünkü şekliyle imar edip kuran Arap Beni Tağlib² kabilesine mensup Hasan b.

2 Hz. İsmail'in soyundan (Adnânî) olan bu kabile İslamiyet'ten önce Cizre ve çevresinde yerleşik bir kabile idi. Nitekim bu kabile ile aynı soydan gelen Bekr b. Vâil'in Beni Şeyban kolu da Cizre'de yerleşikti. Cizreli Mecdüddin İbnü'l-Esîr, İzzeddin İbnü'l-Esîr, Ziyâeddin İbnü'lEsîr kardeşler de Arap Beni Şeyban kabilesine mensupturlar. Bkz. (Avc1, 2010: 39/374; Demirci, 2013: 349-350). 
Ömer et-Tağlibi'ye (v. 250/864) nispet edilerek almıştır (Hamevî, 1977: 138).

İslam ordusunun fethinin akabinde şehir büyük bir gelişim göstererek ilim sanat ve kültür sahasında dünyaca ünlü şahsiyetler yetiştirmiştir. Fen ve dil ilimlerinin yanı sıra fikıh, hadis ve tefsir gibi İslami ilimlerin merkezi haline gelen Cizre bu itibarla müstesna bir konuma sahip olmuştur. (Ali 2017: 123). İslam'1 kabul ettiği ilk dönemlerinden beri zahitleri ile de ünlü Cizre, tasavvuf tarihinde önemli bir yer işgal ederek bu sahada da çok önemli simalara ev sahipliği yapmıştır. Zamanında ve kendisinden sonra irfan ehlinin gönül dünyasını etkilemiş, Şiirde Molla Cami (v. 898/1492), İbn Farız (v. 632/1235) ve Hafiz-1 Şirazî̀ye, (v. 792/1390) tasavvufta ise Mevlânâ Celaleddîn-i Rûmî'ye (v. 672/1273) benzetilmiş Şeyh Ahmed el-Cezerî (v. 1050/1640) (Molla Cezerî) gibi zatların yetiştiği bir merkez haline gelmiştir (Özervarlı, 2005: 30/242).

Hareketli, etkin ve değişik tasavvufi ekollerin yer aldığı şehir, ülkeyi ve İslam coğrafyasının farklı yerlerini irfanî geleneğinin etkisi altına almıştır (Baz, 2013: 141-144). Ancak İslam medeniyetinin önemli şehirlerinden birisi olmasına ve köklü tasavvufi ekolleri barındırıyor olmasına rağmen İslam medeniyetine katkısı ve tasavvuf tarihindeki yeri hakkında yapılan araştırmalar yetersiz kalmaktadır. ${ }^{3}$ Bunda tarihin bazı dönemlerinde kentin yaşadığı siyasi çekişmelerin rolü büyüktür. Buna binaen ülkemizin ilim ve kültür merkezlerinden biri olan bu kadim şehrin kültürünün yanında etkileri hala canlı olan fikri ve tasavvufî akımlarının temsilcilerini bu araştırmayla tanıtmaya çalıştık. Hedefimiz çok kısıtlı yazılı kaynaklarla ve mülakatlarla bu mutasavvifların hayatlarının bir bölümünü verebilmektir.

\section{Kadiriyye Tarikatı}

Kâdirîyye tarikatının kurucusu ve pîri Seyyid Abdulkadir Geylanî'dir. Gavsü'l-A'zam Gavsü's-Sekaleyn, Bazü'leşheb gibi lakapları vardır. (470/1077) yılında İran'ın Geylan eyaletine bağlı Neyf köyünde doğmuş (v. 561/1165-66) yılında da Bağdat şehrinde vefat etmiştir. Nesebi baba tarafindan Hz. Hasan'a (r.a.) anne tarafindan da Hz. Hüseyin'e (r.a.) ulaşmaktadır (Türer, 2018: 156157; Öngören, vd., 2017: 251; Cerrahi, 2013: 207).

Küçük yaşta babasını kaybeden Seyyid Abdulkadir Geylanî annesinin izni ile Bağdat'a ilim tahsili için gitmiş ve devrin ulemasının yanında okumuştur. Tasavvufta mürşidi Ebu Said Mübarek b. Ali el-Muharrimi'dir (v.513/1119). Uzun süre devam eden ilim tahsili ve ardından gelen halvet dönemi ile şer'i ve tasavvufi ilimlerde derin bir nüfuza sahip olmuştur (Kara, 2018: 229; Türer, 2018: 157). Müslümanlar arasında en yaygın tarikatlardan biri haline gelen Kâdirîyye'nin pîri Seyyid Abdulkadir Geylanî'nin şöhreti daha hayatta iken geniş coğrafyalara yayılmıștır (Lings, 2017: 192; Çıkman ty: 199-200).

Tasavvufi öğretileri talebeleri ve eserleri ile günümüze kadar canlı bir şekilde taşınmış olan Seyyid Abdulkadir Geylanî'nin tarikatının Cizre ve bölgede yayılması

3 Cizre mutasavvıfları hakkında şimdiye kadar en çok araştırma yapan "İbrahim Baz" olup çalışmaları ile bu sahada tarihe 1şık tutmuştur. kurulduğu ilk döneme rastlamaktadır. Cizre'de bilinen en eski Kâdirî halifeleri ise Şeyh Seyyid Muhammed Kadri Hazîn'in atalarıdır (Kaya, 1996: 384). Aşağıda Mevlânâ Hâlid-i Bağdâdî'den günümüze kadar Kâdirî hulefâsından tespit edilebilenler kaydedilmiştir.

\subsection{Molla Aburrahman Nurî Huserî (Bilge)}

Molla Abdurrahman Huserî 1875 yilında Cizre'de doğdu. Babasının adı Molla Mahmud'tur, annesinin adı Ayşe Hanım'dır. Soyu Seyyid Abdülkadir Geylânı̂'ye ulaşmaktadır. İlk eğitimini babasından aldıktan sonra sırasıyla Siirtli Molla Hüseyin, Şeyh Ömer Zengânî ve son

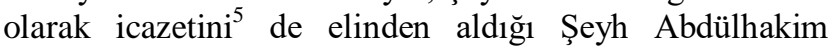
Dîrşevî'nin ${ }^{6}$ yanında okumuştur (A. Bilge, Kişisel Görüşme 9 Ocak 2020).

Mardin'in değişik ilçelerinde müderrislik yapan Molla Abdurrahman Huserî, bir dönem Şırnak Müftülüğü görevini de icra etmiştir. En son Cizre'de karar kıldığ tedris hayatında ülke ve bölge çapında meşhur birçok âlim yetiştirmiştir. Yüksek ilmi kabiliyetinin yanında ibadet ve takvası ile de meşhur olan Molla Abdurrahman Huserî, tasavvufî icazetini dönemin Brifkan ${ }^{7}$ Kâdirî dergâhının postnişininden ${ }^{8}$ almıştır. Akrabaları ve hocaları olan Dîrşevî şeyhlerine ve Şeyh Ömer Zengânî'nin çocuklarına sevgi ve saygısından dolayı açıktan tarikat faaliyetlerini yürütmemiştir.

Daha çok ilmi faaliyetler içinde olan Molla Abdurrahman Huserî, yukarıda zikrettiğimiz gibi aralarında Şeyh Seyyid Muhammed Kadri Hazîn, Şeyh İbrahim er-Rufâî (Salman), Molla Mahmut Bilge ve daha birçok âlim ve velinin yetişmesine vesile olmuştur. Bölgenin manevi dinamiklerinden, Cizre'nin ilim irfan geleneğinin mimarlarından olan Molla Abdurrahman Huserî 1940'lı yılların başında vefat etmiştir (A. Bilge, Kişisel Görüşme, 9 Ocak 2020).

\subsection{Müftü Mahmut Celal (Bilge)}

Müftü Mahmut Efendi 1904 yılında Cizre'de doğdu. Babası Cizre'nin meşhur ulemasından Molla Abdurrahman Huserî, annesi de Cizre eşrafından Ahmed Ağa'nın kızı Ayşe Hanımdır. İlim ve irfan yuvası bir ailenin içinde dünyaya gözlerini açan Müftü Mahmut Efendi, babasının yanında başladığı ilim tahsiline yine onun elinden ilmi icazetini alarak taçlandırmıştır. Tasavvufî icazetini babasının da icazetini aldığı meşhur Brifkan Dergâhı'ndan almıştır. Kendisine icazet veren zamanının Brifkan Dergâhı postnişini Şeyh Memduh Brifkanî (v. 1971)'dir

\footnotetext{
4 Molla Mahmud'un babasının adı Molla Ali Meydinî’dir. Bu zat bölgede meşhur bir âlim olup Şeyh Reşid Dîrşevî'nin (Şeyh Abdülhakim Dîrşevî ve Şeyh Muhammed Nurî Dîrşevî’nin babaları) hocası ve aynı zamanda kayınpederidir. Bkz. (Evliyalar.net, 2020).

5 Bazı araștırmacıların Molla Abdurrahman Huseri'nin ilmi icazetini Şeyh Ömer zengânî'den aldığını bildirmeleri bir sehivdir. Torunun bize verdiği bilgiye göre Molla Abdurrahman icazetini Şeyh Abdülhakim Dîrşevî' den almıştır. Şeyh Ömer Zengânî Cidde'de vefat ettiğinde Molla Abdurrahman'ın 15 yaşında olması bunu teyit etmektedir.

6 Dîrșev (Alkemer) Şınak iline bağlı bir köy olup 25 km., Cizre merkezine ise $24 \mathrm{~km}$. uzaklıktadır.

7 Irak'ın kuzeyindeki Duhok şehrine bağlı bir köydür. Musul şehrinin kuzeydoğusunda Duhok'un ise doğusunda yer almaktadır. Bkz. (Özaydın, 2013: 164).

8 Vefat eden şeyhin yerine geçen, dergâhta posta oturan kiși. Bkz. (Uludağ, 2016: 288).
} 
(Yaşın, 1983: 160; A. Bilge, Kişisel Görüşme, 9 Ocak 2020).

Çok yönlü bir âlim olan ve başladığı tüm okulları başarı ile bitiren Müftü Mahmut Efendi önceden ilkokul öğretmenliği, dava vekilliği, nüfus memurluğu gibi vazifeler icra etmiş̧tir. En sonunda 1948 yılında Müftülük sınavını kazanarak sırasıyla Cizre, Birecik ve Silopi şehirlerinde müftü olarak görev yapmıştır (Bingöl, 2008: 137). Görevinin yanı sıra tedrisat ile de meşgul olarak bölgede ilim ve irfanıyla meşhur birçok âlim yetiştirmiştir. ${ }^{9}$

Ünü bölge ve ülke dışına da taşan Müftü Efendi'ye başta Diyanet İşleri Başkanlığı olmak üzere birçok kurum, kuruluş ve kişi tarafindan cevap verilmek üzere ilmi konularla ilgili değişik sorular yöneltilmiştir. El-Ezher Üniversitesi'nden de kendisine cevaplandırması için sorular yöneltilen Müftü Efendi birçok kıymetli eser de kaleme almıştır ki bunlardan biri de Ay Risalesi adlı eseridir. ${ }^{10}$ Zamanında ilim ve irfan ehlinin sığınaklarından olan ve müstesna bir yeri haiz Müftü Mahmut Bilge, 1974 yllında Cizre'de Hakk'ın rahmetine kavuşmuştur. (Yaşın, 1983: 161).

\section{3. Şeyh Muhammed Hafız (Tozan)}

Şeyh Muhammed Hafız Efendi 1900 yılında doğmuştur. Babasının adı Molla Hâlid, dedesinin adı da Molla Osman olup annesinin adı Havvahan'dır. İlim ve faziletiyle ile meşhur bir ailede dünyaya gelmiştir. Küçük yaşlarda babasını kaybetmiştir. 3-4 yaşlarında gözlerini kaybeden Şeyh Muhammed Hafiz Efendi yine küçük yaşlarda kendini ilim tahsiline vermiş, zamanın önemli âlimlerinden Molla Abdurrahman Huserîden ders almıştır. Kâdirî tarikatına intisap eden Şeyh Muhammed Hafiz Efendi, Brifkan Dergâhı'ndan tasavvufî icazetini almıştır.

Hocasının oğlu ve ders arkadaşı Müftü Mahmut Bilge ile olan münasebetleri Müftü Efendi vefat edene kadar samimi bir şekilde devam etmiştir. Zühd ve takva dolu yaşantısına her biri bir ay süren 33 halvet sıkıştırmıştır. Girdiği riyazetler neticesinde son derece zayıflayan Şeyh Efendi son halvetini Müftü Mahmut Bilge'nin ricasiyla erken bitirmiş̧ir. Genelde yılın üç ayını Hakkari yaylalarında müritleri arasında geçirmiştir. Ağırlıklı olarak Hakkari, Silopi ve Şırnak olmak üzere bir çok yerde müritleri bulunan Şeyh Muhammed Hafiz Efendi 1980 yllında Hakk'ın rahmetine kavuşmuştur (İ. Kaya, Kişisel Görüşme, 10 Ekim 2019).

\section{Nakşibendiyye Tarikatı}

Nakşibendiyye tarikatının pîri Muhammed b. Muhammed el-Buharî'dir. Şah-1 Nakşibend ve Hâce Muhammed Behaeddin olarak da zikredilmektedir. Şâh-1 Nakşibend 718/1318 yılında Buhara şehrinin Kasr-1 Arifan köyünde doğmuş 791/1389 yılında aynı köyde vefat etmiştir. Baba tarafindan nesebi Hz. Hüseyin'e (r.a.) ulaşmaktadır (Cerrahi, 2013: 283).

9 Müftü Mahmut Bilge'nin yetiştirdiği âlimlerden birisi de Cizre'nin son dönem büyük âlimlerinden Molla Abdülkerim Özervarlı'dır. (A. Bilge, kişisel iletişim, 9 Ocak 2020).

10 Aya gidilmeden önce kaleme alınmıştır. Akli ve nakli deliller ışı̆̆ında aya gitmenin mümkün olduğunu ispata yönelik kıymetli bir eserdir.
Küçük yaşta intisap ettiği Hacegân yolunun büyüklerinden Şeyh Muhammed Baba Semmasî (v. 736/1335-36 [?]) tarafindan manevi evlatllğa kabul edilmiştir. Yine şeyhi tarafindan tasavvufi terbiyesi Seyyid Emir Külal'e (v. 772/1370) havale edilmiştir. (Nebhânî, 2001: 240-241). Seyyid Emir Külal'in yanı sıra Mevlânâ Arif, Yesevî halifelerinden Kasım Şeyh ve Halil Ata'dan da feyiz almıştır. Üveysî olarak Abdülhalık Gücdüvanî’nin (v. 617/1220) ruhaniyetinden de istifade ettiği rivayet edilir (Yllmaz, 2009: 290). İslam âleminin en yaygın tarikatı haline gelen Nakşibendiyye tarikatı, şeriata bağl1lık üzerinde durmuş ve hafî zikri tercih etmiştir. (Türer, 2018: 162). Yolunun esasının sohbete dayalı olduğunu belirten Şah-1 Nakşibend Hâce Muhammed Behaeddin yine "halvet der encümen" yani "zahirde halk ile beraber iken batında Hak'tan ayrılmamak" ilkesini öncelemiştir (Bardakçı, 2016: 301).

Muhtelif zamanlarda Nakşibendîliğin yanında değişik isimlerle de anılan bu yol Mevlanâ Hâlid-i Bağdâdî'den sonra Nakşibendiyye-i Hâlidiyye olarak anılmıştır. İtikad ve amelde Ehl-i Sünnet'ten ödün vermeyen Nakşî-Hâlidî yolu Ortadoğu'da büyük bir dini ve tasavvufî hareketliliğe sebep olmuştur (Kavak, 2017: 2-5). Tarihi süreçte NakşîHâlidî yolunun en önemli merkezlerinden biri haline gelen Cizre'de bilinen en eski Nakşî mutasavvıfi ise Şeyh Ahmed el-Cezerî (Molla Cezerî)'dir (Tunçer, 2006: 433; Kavak, 2015a: 52).

Cizre'de Nakşi-Hâlidî yolunun iki önemli kolu bulunmaktadır:

Mevlânâ Hâlid-i Bağdâdî'nin yetiştirdiği birçok halifesi içinde Cizre'li Şeyh Hâlid-i Cezerî (v. 1839) de bulunmaktadır (Baz, 2013: 140). Cizre'ye gelerek yetiştirmek için bir halife adayını seçmesi, Mevlânâ Hâlidi Bağdâdî'nin Cizre'ye verdiği önemin bir göstergesidir. Cizre o tarihten beri Nakşî-Hâlidî yolunun tasavvufi terbiyesi altına girmiştir. Mevlânâ Hâlid-i Bağdâdî'nin baş halifesi Şeyh Osman Siracüddin et-Tavîlî’nin torunu Şah-1 Pîr olarak da bilinen Şeyh Muhammed Ali Hüsameddin'in (v. 1939) Cizre'den ehil görüp yetiştirdiklerine hilafet vermesi üzerine şehir, Nakşî-Hâlidî yolunun bayraktarlığını yapan merkezlerden biri haline gelmiştir (Kaya, 1996: 384; Nakşibendî, ts: 28-34; Müderris, 1983: 400-401).

\section{1. Şeyh Hâlid-i Cezerî Kolu}

Şeyh Hâlid-i Cezerî, Basret köyüne gitmeden bir dönem Cizre merkezde irşat faaliyetlerinde bulunduğu için tercüme-i halini aşağıda verdik.

\subsection{1. Şeyh Hâlid-i Cezerî}

Şeyh Hâlid-i Cezerî̀nin doğum tarihi bilinmemektedir. Cizre'nin tanınmış ailelerinden Hacı Züraf ailesine mensuptur. İlim tahsilini Cizre'nin köklü medreselerinde tamamlamış ve zamanının tanınan büyük âlimlerinden olmuştur (Seydaiyye, 2019).

Mevlânâ Hâlid-i Bağdâdî, Şam'a gitmek üzere yola çıktığında Cizre'ye uğramıştı. Cizre'de görüştüğü ilim ehli arasında Molla Hâlid-i Cezerî'nin halini beğenmiş ve onu yanına alarak Şam'a götürmüştü. Şeyh Hâlid-i Cezerî, Şam'da Mevlânâ Hâlid-i Bağdâdî'nin gözetiminde seyr u 
sülûkünü tamamlamış ve hilafet ile taltif edilerek irşad için memleketi Cizre'ye gönderilmiştir. Ayrıca Cizre'de yaptığı irşadın tesiri ortaya çıkıp halk istenilen ahlaki düzeye gelinceye kadar şehri terk etmemesi emrini almıştı. Halkın bu manevi olgunluğu yakaladığı anlaşılınca Şeyh Hâlid-i Cezerî, Gabar dağlarındaki Basret Köyü'ne ${ }^{11}$ yerleşmiştir (Evliyalar, 2020).

Basret Köyü'nde medrese ve tekkesini kuran Şeyh Hâlid-i Cezerî, burayı Nakşî-Hâlidîliğin önemli merkezlerinden biri haline getirmiştir. (Sarı, 2016: 413-414). Sayısız ilim ve irfan ehlinin yetiştiği bu merkezin kurucusu Şeyh Hâlid-i Cezerî 1839 yılında vefat etmiştir. Ardında Şeyh Salih-i Sıpkî (v. 1852) ve Şeyh Hamid-i Mardinî (v. 1882) gibi iki önemli ilim ve irfan ehlini halife birakarak bu yolun neşvünema bulmasına vesile olmuştur (Baz, 2013: 144).

\subsection{2. Şeyh Ömer Zengânî El-Cezerî}

Doğum tarihi hakkında bilgi bulunmayan Şeyh Ömer Zengânî, Cizre'den yaklaşık yetmiş km uzaklıkta olan Mardin ili Dargeçit ilçesine bağlı Kureyşa köyünde dünyaya gelmiştir. Şeyh Ömer Zengânî’nin soyu, nesebi Resulullah (s.a.v)'a dayanan "Pîr-i Kureyş" diye bilinen zata ulaşmaktadır. Babasının adı Mustafa Efendi, annesinin adı ise Hacer Hanım'dır (Işık, ts: 23; Seydaiyye 2019).

İlim ve fazilet sahibi bir ailenin evladı olarak dünyaya gelen Şeyh Ömer Zengânî daha küçükken babasını kaybetmiştir. Annesi başka bir evlilik yapınca teyzesi onu sahiplenmiş ve onu ilim tahsiline yönlendirmiştir. Basret dergâhı ve medresesinin başında bulunan Şeyh Hâlidi Zebarî (v. 1863)'nin yanında hem ilmi hem de tasavvufî icazetini alarak kendisinden sonraki postnişin olmuştur (Baz, 2013: 151-152).

Hocası ve şeyhi Şeyh Hâlid-i Zebârî'nin vasiyeti üzerine medresesinin bulunduğu Cizre'ye bağlı Düzova köyünden Basret'e gitmiş ve şeyhinin mahdumu Şeyh Hüseyin Basretî'nin (v. 1914) zahiri ve batıni ilimlerde yetişmesinin tamamlanmasına kadar orada kalmıştır. Daha sonra tekrar döndüğü Düzova köyünden Cizre merkeze taşınmış medrese ve dergâh faaliyetlerini burada icra etmiştir. Cizre eşrafindan bazı mürit ve sevenleriyle çıktığ 1 hac yolculuğu dönüşünde Cidde şehrinde 1890 yılında vefat etmiştir (Evliyalar, 2020).

\subsection{3. Șeyh Abdülhakim Ed-Dîrșevî}

Şeyh Abdülhakim Ed-Dîrşevî 1856 yılında Cizre'nin yakın köylerinden Düzova'da (Hoser) dünyaya gelmiştir. Babası Şeyh Reşid Dîrşevî (v. 1868) olup annesinin adı Fatma'dır. Babası Şeyh Reşid Dîrşevî hac farizasını ifa ederken Mekke-i Mükerreme'de vefat etmesi üzerine yetim kalmıştır (yahyamunis, 2019).

Şeyh Hâlid Zebârî'nin de tavsiyesiyle enişteleri Şeyh Ömer Zengânî hem kendisinin hem de küçük kardeşi Şeyh Muhammed Nurî'nin maddi ve manevi eğitimleri ile ilgilenmiştir. İlmi tahsilini yanında tamamladığı hocası Şeyh Ömer Zengânî'den aynı zamanda tarikat icazetini de almıştır. Şeyh Ömer Zengânî'nin vasiyetine binaen

11 Cizre'nin kuzeydoğusuna düşen köy, Uludere ilçesine bağlıdır. kendisinden sonra postnişin ve baş müderris olan Şeyh Abdülhakim Dîrşevî ilmi kişiliği ile bölgede meşhur olmuş ve zaman zaman Cizre'ye gelen Bediüzzaman Said Nursi'nin (v. 1960) de takdirini kazanmıştır (Bingöl, 2008: 114; Evliyalar, 2020).

Şeyh Abdülhakim Dîrşevî kendisinden sonra yerine postnişin olarak ablasının oğlu Şeyh Muhyiddin elCezerî’yi vasiyet etmiştir. 1905 yılında vefat ederek sonradan kardeşi Şeyh Muhammed Nuri Dîrşevî'nin adıyla anılacak türbeye defnedilmiştir (Adak, 2009: 20).

\subsection{4. Şeyh Muhyiddin El-Cezerî}

Şeyh Muhyiddin El-Cezerî 1875/1876 yılında Cizre'de dünyaya gelmiştir. Babası Şeyh Ömer Zengânî'dir. Annesi, Şeyh Reşid Dîrşevî’nin kızı Halime Hanım'dır. Sıkıntılı bir dönemde irşad vazifesini üstlenen Şeyh Muhyiddin el-Cezerî medrese ile ilgilenmesi için küçük kardeşi Şeyh Siracuddin el-Cezerî (v. 1920)'yi görevlendirmiştir. Şeyh Hüseyin Basretî ile bir süre Diyarbakır ve Halep'te bulunduktan sonra tekrar memleketi Cizre'ye geri dönmüştür. Yerine postnişin olarak küçük dayısı Şeyh Muhammed Nurî Dîrşevî’yi vasiyet eden Şeyh Muhyiddin el-Cezerî 1914 yilında Cizre'de vefat etmiştir (Seydaiyye, 2019).

\subsection{5. Şeyh Muhammed Nuri Ed-Dîrşevî}

Şeyh Muhammed Nuri Ed-Dîrşevî 1868 yılında Cizre'nin yakın köylerinden Düzova'da (Hûser) dünyaya gelmiştir. Babası Şeyh Reşid Dîrşevî'dir. Annesi ise Fatma Hanım'dır. Hocası ve şeyhi Şeyh Ömer Zengâni'nin yanında başladığı ilim tahsilini şeyhinin vefatı üzerine abisi Şeyh Abdülhakim Dîrşevî'nin yanında tamamlamış ve ilmi icazetini de ondan almıştır (Bingöl, 2008: 144; yahyamunis, 2019).

Başında bulunduğu medreseyi ablasının ve Şeyh Ömer Zengâni'nin iki oğluna ${ }^{12}$ bırakarak kendisini tamamıyla halkın sorunlarını çözmeye adamıştır. Cizre çevresindeki köy ve aşiretlere sürekli irşad ve sulh faaliyetleri için giderek emr-i bi'l-mâruf ve nehy-i ani'l- münker vazifesini icra etmiştir (Seydaiyye, 2019).

Şeyh Muhammed Nuri Dîrşevî en son Cizre ve çevresindeki halkı Fransız işgaline karşı ayaklandırmıştır. Yapmış olduğu bu gayretler zamanın hükümeti tarafindan kendisine gönderilen bir beratla takdir edilmiştir. 1924 yılında doğduğu köy olan Düzova'da vefat eden Şeyh Muhammed Nuri Dîrşevî kendi adı ile anılan türbeye defnedilmiştir (Baz, 2011: 351).

\subsubsection{Seyh Muhammed Said Seydâ El-Cezerî}

Şeyh Muhammed Said Seyda el-Cezerî 1890 yılında Cizre'de doğmuştur. Babası Şeyh Ömer Zengânî olup annesi Şeyh Reşid Dîrşevî'nin kızı Halime Hanım'dır. Daha bir yaşında iken babası hac dönüşü Cidde'de vefat etmiştir. Küçük yaşlarda başladığı ilim tahsilini dayıları Şeyh Muhammed Nuri Dîrşevî ve Şeyh Abdülhakim Dîrşevî yanında sürdüren Şeyh Muhammed Said Seyda ilmi icazetini de ağabeyi Şeyh Siracuddin el-Cezerî'den almıştır (Işık, ts: 23-24). 
Ağabeyinin vefatından sonra medresenin başına geçen Şeyh Seyda el-Cezerî çok sayıda ilim talebesi yetiştirmiştir. Dayısı ve aynı zamanda kayınpederi olan Şeyh Muhammed Nuri Dîrşevî’nin vasiyetiyle kendisinden sonra tarikat vazifesini üstlenmiştir. Şeyh Muhammed Said Seyda el-Cezerî son derece şefkat ve merhamet sahibi bir zat olarak tanınmıştır. İlim, ibadet ve takva ile dolu bir hayat süren Şeyh Seyda el-Cezerî 1968 yılında vefat etmiştir (Özdirek, 2012: 226).

\subsection{7. Şeyh Muhammed Nurullah Seydâ El-Cezerî}

Şeyh Muhammed Nurullah el-Cezerî 1949 yılında Cizre'de dünyaya gelmiştir. Şeyh Muhammed Said Seyda el-Cezerî'nin oğlu olup annesi Basret şeyhlerinden Şeyh Celaleddin kızı Taybet hanımdır. Küçük yaşlarda parlak bir zekâya sahip olduğu müşahede edilen Şeyh Muhammed Nurullah el-Cezerî babasının yanı sıra Molla Abdurrahman Erzen (v. 1986)'in yanında da okumuştur. (Yaşın, 1983: 164; Bingöl, 2008: 145; Baz, 2016: 351).

En son ilmi icazetini de babasının halifesi Şeyh Fahreddin el-Arnâsî (v. 1972)'den almıştır. Çok cevval ve hareketli bir kişiliğe sahip olan Şeyh Nurullah Seyda el-Cezerî irşad ve davet faaliyetleri için sürekli seyahat etmekle beraber birçok eser de telif etmiştir. Yine en son 1985 yılında irşad faaliyetleri için çıktığı bir seyahatte trafik kazasında vefat etmiştir (Göksu, 2010: 647-648; Agitoğlu, 2015: 8-9).

\section{2. Şeyh Osman Siracuddin Et-Tavîlî Kolu}

Müntesipleri Nakşî-Hâlidî-Osmanî olarak da anılan bu tarikin pîri Şeyh Osman Siracüddin et-Tavîlî, 1781 yılında Irak'ın Halepçe şehrine bağlı Tavîle ${ }^{13}$ köyünde dünyaya gelmiştir. Babası Seyyid Hâlid b. Abdillah Hz. Hüseyin neslinden olup annesi Halime Hanım da Hz. Hasan'ın neslindendir. Şeyh Said Seyfeddîn'in bu yoldan hilafet almasından itibaren Cizre'de çok sayıda halife yetiştiren ve etkinliğini günümüze kadar devam ettiren bir diğer Nakşî-Hâlidî koldur (Müderris, 1983: 376; Baytâr, 1993: 1052; Kavak, 2015b: 262-263).

Daha küçük yaşta Tavîle köyünde başladığı tahsil hayatını bölgedeki diğer meşhur medreselere iltihak ederek sürdürmüştür. Medrese eğitimini tamamlamasına rağmen kendisinde bulunan ilim iştiyakından ve tasavvufa olan ilgisinden dolayı Bağdat'ta bulunan Geylanî Medresesi'ne gitmiştir. Burada daha önce tanıdığı Mevlânâ Hâlid-i Bağdâdî'ye intisap etmiştir. Mevlânâ Hâlid-i Bağdâdî'nin ilk tasavvuf icazetini verdiği baş halifesidir (Baytâr, 1993: 1052; Kaya, 1996: 384).

Şeyh Osman Siracüddin'i çok seven ve ona pek değer veren Mevlânâ Hâlid-i Bağdâdî onun hakkında; "Hâlid renc-i hurde, Osman genci burde." yani "Hâlid zahmet çekti, Osman Hazîneyi götürdü." diyerek halinin varisi olduğuna işaret etmişti. Mevlânâ Hâlid-i Bağdâdî’nin halifeleri arasında en çok halife yetiştiren ve geniş coğrafyalarda etkili olan Şeyh Osman Siracüddin Irak, İran, Türkiye ve İslam coğrafyasının daha birçok yerinde etkili olmuştur. Birçok Hristiyan ve Yahudi'nin Müslüman olmasına vesile olmuştur. İran'ın Sünni kesimlere yönelik Şii yayılmacılığına halifeleri vasıtasıyla set olmuş ve çok

13 Irak'ın kuzeyinde ve İran sınırında Halepçe'ye bağlı bir köydür. Nakşî-Hâlidî yolunun en önemli merkezlerinden birisidir. sayıda Şiî’nin de Ehl-i Sünnet inancını benimsemesine sebep olmuştur. (Kavak, 2012: 93-94; Kaya, 1996: 10; Baytâr, 1933: 1052). İrşat faaliyetlerinin yanı sıra kurduğu medreselerle de medrese ve tekke birlikteliğinin en güzel örneklerini veren Şeyh Osman Siracüddin'in dergâhına her çeşit ırk ve mezhepten insanlar akın etmiştir (Müderris, 1983: 379).

Hayatını ilim ve talebe yetiştirmek, insanlara doğru yolu öğretmekle geçiren Şeyh Osman Siracüddin et-Tavîlî 1867 yılında Tavîle'de vefat etmiştir. Yerine büyük oğlu Şeyh Muhammed Behaeddin-i Evvel et-Tavîlî geçerek dergâh ve medrese hizmetlerini devam ettirmiştir (Kavak, 2012: 95). Şeyh Muhammed Behaeddîn Evvel et-Tavîlî'den (v. 1881) sonra yerine oğlu Şeyh Muhammed Ali Hüsameddin et-Tavîlî geçerek tarikatın gelişip yayılmasını sağlamıştır. Şeyh Muhammed Ali Hüsameddin et-Tavîlî'nin şöhreti her tarafa yayılmıştır. Zamanında tasavvuf taliplerinin en büyük mercii konumuna gelen Tavîle Dergâhı'ndan hilafet alan ilk Cizre'li, Şeyh Muhammed Said Seyfeddîn olmuştur. Şeyh Muhammed Ali Hüsameddin ardında on binlerce halife ve sayısız mürit bırakarak 1939 yılında hakkın rahmetine kavuşmuştur (Müderris, 1983: 379 Kaya, 1996: 132).

\subsubsection{Seyh Muhammed Saîd Seyfeddîn Şeyh-i Meczûb $b^{14}$}

Şeyh Muhammed Saîd Seyfeddîn 1874 yılında Cizre'de doğdu. Babası Cizre'nin eşrafindan iyi huy ve cömertliğiyle meşhur olmuş Hüseyin Mazlum Efendi olup annesi saliha ve veli zatlardan Seyyide Halime'dir. ${ }^{15}$ Cizre'nin önde gelen âlim ve hatiplerinden olan amcası Molla Muhammed Beşir Efendi gibi Şeyh Muhammed Said Seyfeddîn de küçük yaşta ilim tahsiline başlamıştır (Yaşın, 1983: 155).

Gördüğü manevi işaretler üzerine genç yaşta Tavîle'de bulunan dönemin en meşhur Nakşî-Hâlidî mürşidi, Şeyh Muhammed Ali Hüsameddin'in yanına giderek seyr u sülûkünü onun gözetiminde tamamlamıştır. Şeyhi tarafindan hilafet verilip Cizre'ye gönderildiği tarihten sonra özelde Cizre'ye ve genelde bölgeye irşadı ile büyük bir iz bırakmıştır (Kaya, 1996: 131-132; Bingöl, 2008: 170-171).

Şeyh Muhammed Said Seyfeddîn bölgeyi ve şehri cezbedici yeni bir tasavvufî ekolle tanıştırmıştır. Eşkıya ve inat ehline cebri irşad ile tasarrufta bulunmasıyla da

14 Şeyh Muhammed Saîd Seyfeddîn Efendi’ye "meczûb" lakabının verilmesinin sebebi şu hikâyedir: Bir sabah tenha bir saatte mescide gitmiştir. Mescitte Peygamber Efendimiz (s.a.v.)'in başkanlığında kurulan mecliste hayatta ve vefat eden büyük veliler toplanmıştı. Bu mecliste Şeyh Muhammed Saîd'in yetiştirilmesi Hz. Peygamber (s.a.v.) tarafindan zamanının en büyük velisi Şeyh Muhammed Ali Hüsameddin et-Tavîlî’ye tevdi edilmiştir. Şeyh Muhammed Saîd Bu manevi işaretten sonra ailesinden Tavîle'ye gönderilmeyi istemiştir. Talebine cevap verilmeyince artık hiç kimseyle konuşamamış ancak yazı veya işaret ile iletişim sağlayabilmiştir. Geçirdiği bu manevi halden ancak üç sene sonra üstadının huzuruna varabilen Şeyh Efendi mürşidinden hilafet alarak Cizre'ye gelmiştir. Hilafetinin ilk üç senesinde Cizre' de büyük bir cezbe haliyle yaşamıștır. Bazen bu manevi halin tesiriyle sokağa çıkar ve onu gören kim varsa ona da bu cezbe hali sirayet ederek peşine takılır hep beraber "ya kalbu salli ala'n-Nebiyy'il-Hâdî" kasidesini okurlardı. Tavîle'ye mürşidinin huzuruna ikinci sefer çıtığında artık bu engin cezbe hali son bulmuş Şeyh Efendi velayetin kemâlâtına ulaşarak müstesna bir makama erişmiştir. Bkz. (Kaya, 1996: 130-134). 15 Seyyid Muhammed Kadri Hazîn Haşimî'nin halasıdır. 
ünlenen Şeyh-i Meczûb Şeyh Muhammed Said Seyfeddîn aşk ve cezbe ile her sınıf insanı dergâhına doğru çekmiş, onları kendine hayran bırakmıştır. Şeyh Muhammed Said Seyfeddîn 1916 yılında genç yaşta vefat ederken ardında birçok halife ve büyük bir mürit kitlesi bırakmıștır. Bunların arasında Diyarbakır'ı irşadı ile fethetmiş Şeyh İsmail (v. 1925), Şam'da irşad faaliyetlerini yürüten Şeyh Reşid, büyük velilerden Şeyh Abdülaziz ve tüm bereketlerine varis olarak görülen Şeyh Seyyid Muhammed Kadri Hazîn Haşimî gibi daha niceleri sayılabilir (Kaya, 1996: 134-136; Yaşın, 1983: 164).

\subsection{2. Şeyh Seyyid Muhammed Kadri Hazîn Haşimî}

Şeyh Seyyid Muhammed Kadri Hazîn Haşimî 1898 yılında Cizre'de doğdu. Babası Cizre'nin köklü ailelerinden Seyyid Haşim olup annesi ise aynı aileden Seyyide Sefika'dır. Șeyh Seyyid Muhammed Kadri Hazîn'in ataları Cizre'ye gelmeden bir süre önce şehri kasıp kavuran, ani ölümlerle adeta boşaltan bulaşıcı bir hastalık istila etmişti. $\mathrm{Bu}$ durumdan kurtulma ümidi ile şeyhin ataları davet üzerine Cizre'ye getirilen hakiki şecereye sahip ilim ve velayet sahibi kimselerdi.

Daha küçük yaşlarda önce annesini sonra da babasını kaybeden Şeyh Seyyid Muhammed Kadri Hazîn, zahiri ilimleri Cizre'nin meşhur ulema ve evliyasından Molla Abdurrahman Huserî'den tahsil etmiş, icazetini de ondan almıştır. Hocası gördüğü manevi işaretlerden onun ilerde büyük âlim ve velilerden olacağını keşfetmiştir. Bu yüzden ilim ve takva yolunda sülûk etmesi için ona sürekli telkinlerde bulunmuştur. Daha küçük yaşlarda da Cizre'ye yeni bir manevi ekol getiren, bölgede adından söz ettiren Şeyh Said Seyfeddîn'in sohbetlerine devam ederek kendisine intisap etmiştir. Şeyh Said Seyfeddîn'in vefatı üzerine Tavîle'de bulunan Şeyh Muhammed Ali Hüsameddin'in dergâhına giderek seyri sülûk mertebelerini yanında tamamlamış ve kendisinden hilafet almıştır (Kaya, 1996: 382; Bingöl, 2008: 143).

Şeyh Muhammed Ali Hüsameddin et-Tavîlî bir başkasına göstermediği ilgi ve sevgiyi tüm halifelerinden üstün tuttuğu Şeyh Seyyid Muhammed Kadri Hazîn'e göstermiştir. ${ }^{16}$ Şeyhinin pek büyük iltifatlarına mazhar olan Şeyh Seyyid Muhammed Kadri Hazîn şeyhinin mutlak halifesi "reisü'l-hulefa" (baş halife) unvanını almıştır (Kaya, 1996: 34). Özelde Cizre ve havalisi genelde Türkiye'nin birçok yerinde mürit ve bağıları olup maddi ve manevi sorunlarıla birebir ilgilenmiştir. İnsanları irşad ederken de sevgi, şefkat ve merhamet ile muamele etmiştir. Maddi ve manevi yüksek konumuna karşın tevazuda eşsiz olan Şeyh Seyyid Muhammed Kadri Hazîn cömertlikte de sınır tanımamıştır. Geride bıraktığı divanı Allah ve peygamber sevgisinin zirve örnekleriyle, zevk edilen seyr u sülûk mertebelerinin açıklanmasıyla doludur. Seyyid Muhammed Kadri Hazîn 63 yaşında Cizre'de vefat etmiş ve Hz. Nuh'un a.s. kabrinin

16 Bir gün Șeyh Muhammed Ali Hüsameddin et-Tavîlî dergâhta halife ve müritlerden müteşekkil büyük bir cemaat içinde Şeyh Seyyid Muhammed Kadri Hazîn'in cübbesini tutarak "yarın Hz. Peygamber s.a.v. bana diyecek ki: Ali! Cenâb-1 Mevlâ o dünyada sana çok büyük ve yüksek nimetler verdi. Sen o dünyadan bana getirdin? Diyecek. Ben de size Seyyid Kadri'yi getirdim, diyerek iftiharım olarak seni hediye edeceğim, demiştir." (Kaya, 1996: 389). ayakucuna defnedilmiştir (Kaya, 1996: 396-403; Yaşın, 1983: 157).

\subsection{3. Şeyh Muhammed Nesim Haşimî}

Şeyh Muhammed Nesim Haşimî 1933 yılında Cizre'de doğdu. Babası Şeyh Seyyid Muhammed Kadri Haşimî olup annesi de Seyyide Hacer Hanım'dır. İlk temel dini bilgilerini babasından alan Şeyh Muhammed Nesim Haşimî daha çok küçükken üzerinde olgunluk alametleri belirmiştir. Babası kendisinden sonra posta oturacak kişi olarak onu işaret etmiş̧ir (Nakşibendî, ts: 36-37; K. Haşimî, Kişisel Görüşme, 16 Ekim 2019).

Babası hayatta iken tayin edildiği Diyarbakır'ın Çınar ilçesinde bir süre öğretmen olarak görev yapan Şeyh Muhammed Nesim Haşimî, babasının vefatı üzerine öğretmenlikten istifa etti. Tekrardan ilim tahsiline dönerek Molla Said Hetmî (v. 1991)'nin yanında kısa sürede ilmi tahsilini tamamladı. Babasının vasiyeti ve halifelerinin de tasvibiyle Tavîle Dergâhı'na ${ }^{17}$ seyr u sülûk eğitimi için gitmiştir. Şeyh Muhammed Ali Hüsameddin'in oğlu Şeyh Muhammed Bahaeddin es-Sânî (v.1971)'den tasavvufî icazetini alarak dergâhın başına geçmiştir.

Toplumun ıslahı için çalışmalara ara vermeden devam eden Şeyh Muhammed Nesim Haşimî'nin sohbetlerine bilhassa gençlerden büyük bir teveccüh oluşmuştur. Çok titiz olup giyim kuşamına dikkat eden ilim ve takva sahibi Şeyh Muhammed Nesim Haşimî cesaret ve cömertlikte de meşhurdur. Yüce hali ve ferasetiyle ilgili halk arasında birçok menkıbesi anlatılan Şeyh Muhammed Nesim Haşimî 1972 yılında genç yaşta hakkın rahmetine kavuşmuştur (K. Haşimî, kişisel iletişim, 16 Ekim 2019).

\subsection{4. Şeyh Muhammed Bahir Haşimî}

1934 yılında Cizre'de doğdu. Babası Şeyh Seyyid Muhammed Kadri Haşimî olup annesi de Seyyide Hacer Hanım'dır. Şeyh Muhammed Nesim Haşimî'nin vefatından sonra yerine Nakşî-Hâlidî-Hüsâmî tarikatının Cizre'deki postnişini olmuştur. İlk dini ve tasavvufî eğitimini babasından almıştır. Sonradan Molla Said Hetmî ve Molla Abdülkerim Özervarlı (v. 2015)'nın yanında ilmi tahsiline devam etmiştir (Yaşın, 1983: 157; R. Haşimî, Kişisel Görüşme, 18 Ekim 2019).

Tasavvufî icazetini babasının vasiyetine uyarak Tavîle'de merkez dergâhın postnişini Şeyh Ahmed Nureddin Hüsâmî (v. 1989)' den $^{18}$ alarak vazifesine başlamıştır. Derin irfanî sohbetleriyle sevenlerinin gönlüne taht kuran Şeyh Muhammed Bahir Haşimî'nin hastalıklara vukufiyeti şöhret bulmuştur. Bu sebeple hemen hemen her gün hanesi dertlerine deva arayanlarla dolmuştur. Kendisine müracaat

17 Seyh Seyyid Muhammed Kadri Haşimî evlatlarına tasavvufî icazetlerini kendisi gibi gidip Tavile'den almaları gerektiğini bunun Hâlidî-Osmanî-Hüsamî dergâhına bir vefa borcu olduğunu belirterek vasiyet etmiştir. Kendisinden sonra sırasıyla Cizre'de dergâhın postnişini olan Şeyh Muhammed Nesim Haşimî, Şeyh Muhammed Bahir Haşimî, ve halihazırda postnișin olarak vazifesine devam eden Șeyh Muhammed Bakır Haşimî, Tavile'de seyr u sülûk eğitimlerini tamamlayarak icazetlerini almışlardır.

18 Hâlihazırda Hâlidî-Osmanî-Hüsami tarikatının tek postnişini Kuzey Irak'ta hizmetlerini sürdüren Şeyh Muhammed Ali Hüsameddin-i Sânî olup babası tarafindan şahitler huzurunda yazılı vasiyet bırakılarak seçilmiş̧ir. Bkz. (Nakşibendî, ts: 97-99). 
edenlere şefkatle muamele ederek gerekli tavsiyelerde bulunmuştur.

Maddi ve manevi hastalıklara yakalanmış insanlara deva olmaya çalışan adeta bir "Lokman-1 Hakîm" gibi hizmet eden Şeyh Muhammed Bahir Haşimî son yıllarda hicret ettiği Adana'dan manevi bir işaret alarak memleketi Cizre'ye geri döner. Bu süre zarfinda sevenleri ve Cizre halkı ile buluştuktan kısa bir süre sonra 1995 yılında vefat ederek babası ve ağabeyinin bulunduğu türbeye defnedilmiştir $^{19}$ (R. Haşimî, Kişisel Görüşme, 18 Ekim 2019).

\subsection{5. Şeyh Saîd Ömer Bajarî20 (Küni)}

Şeyh Said Ömer Bajarî 1887 yllında Cizre'de dünyaya geldi. Babasının adı İsmail, annesinin adı ise Medine'dir. Soyu Peygamber Efendimiz (s.a.v.)'in amcası Hz. Abbas (r.a)'a dayanmaktadır. İlim tahsilini dönemindeki âlimlerin yanında tamamlamıştır. Şeyh Said Seyfeddîn'in vefatından sonra Tavîle'ye giderek Şah Muhammed Ali Hüsameddin'den tarikat icazetini alarak Cizre'deki halifeleri arasına girmiştir.

Bakırcılar çarşısındaki mescitte namazlarını eda eder ve orada sohbetlerini icra ederdi. Birçok problemde kendisine müracaat edilen ve halkın sorunlarına çare olmaya çalışan Şeyh Said Ömer Bajarî'nin Cizre'de mürit çevresi olduğu gibi Ankara, İstanbul, Gaziantep, Diyarbakır gibi şehirlerde de müritleri bulunmaktaydı. Şeyh Efendi 1972 yılında Cizre'de vefat ederek Cizre asri mezarlı̆̆ında kendisinden bir süre önce vefat eden oğlu Şeyh Zeynel Abidin'in yanına defnedilmiştir (M. R. Küni, Kişisel Görüşme, 12 Ekim 2019).

\subsection{6. Şeyh Zeynel Abidin (Küni)}

Şeyh Abidin 1928 yilında Cizre'de dünyaya geldi. Şeyh Said Ömer Bajarî’nin oğlu olup annesinin adı Rızkiye'dir. Babasından ilim tahsil ettiği gibi dönemin meşhur âlimlerinden Şeyh Seyda el-Cezerî, Molla Said Hetmî ve Molla İbrahim Sevik'ten de ders almıştır.

Daha sonra kendi adı ile anılan camide talebe yetiştiren Şeyh Zeynel Abidin genellikle ilmi tedrisatta bulunmakla beraber babasından da tasavvufî icazetini almışıır. İlim ve tedrisat ile ömrünü geçiren Şeyh Zeynel Abidin Efendi daha kırk yaşında iken 1968 senesinde Cizre'de vefat etmiştir (M. R. Küni, Kişisel Görüşme, 12 Ekim 2019).

\subsection{7. Şeyh Abdülaziz (Benzer)}

Cizre'de dünyaya gelen Şeyh Abdülaziz Efendi'nin babasının adı Emin'dir. Doğum tarihi bilinmemektedir. Çocukluğunda başlamış olduğu ilim tahsilini dönemin ünlü mutasavvıf ve âlimlerinden Şeyh Abdülhakim edDîrşevî'nin yanında tamamlamış ve ilmi icazetini de ondan almıştır.

Bir sabah namazı vaktinde hocası ve tasavvufta takip ettiği Şeyh Abdülhakim'in mescidine doğru gitmeye niyet eden Şeyh Abdülaziz oraya yetişemeyeceğini anlamıştır. Bunun üzerine Tavîle'de bulunan Şah Muhammed Ali

19 Hâlihazırda Hâlidî-Osmanî-Hüsami tarikatının Türkiye'deki tek temsilcisi Şeyh Seyyid Muhammed Bakır Haşimı̂’ dir.

20 Bajarî kelimesinin anlamı şehirli demektir.
Hüsameddin'den hilafet alarak Cizre'de yeni manevi ve feyizli bir yol açan Şeyh Muhammed Said Seyfeddîn'in mescidine gitmiştir. Sabah namazından sonra Şeyh Muhammed Said Seyfeddîn hatm-i hâcegân'a başlamışıır. $\mathrm{Bu}$ esnada Şeyh Abdülaziz'e büyük manevi fetihler açılmış ve Şeyh Abdülhakim'in tensibiyle de bir daha bu dergâhı terk etmemiştir.

İlk tasavvufî eğitimini Şeyh Said Seyfeddîn'in yanında alan Şeyh Abdülaziz Efendi, Şeyh Muhammed Said Seyfeddîn vefatı üzerine tarikat pîri Şah Muhammed Ali Hüsameddin'in halifesi olma payesine erişmiştir. Cizre'nin manevi atmosferine katkıda bulunan Şeyh Abdülaziz Efendi, Şah Muhammed Ali Hüsameddin'in diğer halifeleri gibi kendilerine müracaat eden talipleri daha çok reisü'l-hulefầ olan Seyyid Muhammed Kadri Hazîn Haşimî’ye yönlendirmiştir. İlim, irfan ve yüksek haller sahibi Şeyh Abdülaziz Efendi, Cizre'de vefat ederek Cizre Asri Mezarlı̆̆ı'na defnedilmiştir (A. Benzer, Kişisel Görüşme, 9 Ekim 2019).

\subsection{8. Şeyh Mustafa (Benzer)}

Şeyh Mustafa Efendi 1917 yllında Cizre'de dünyaya gelmiştir. Annesinin adı Vesile olan Şeyh Mustafa, Şah Muhammed Ali Hüsameddin'in Halifesi Şeyh Abdülaziz Efendi'nin oğludur. Şeyh Mustafa Efendi hadis ve tefsir ilimlerini babasının yanında okumuştur. Babasından tasavvufî terbiyeyi de almasına rağmen onun hakiki mürşidi ve şeyhi, Seyyid Muhammed Kadri Hazîn Haşimî olmuştur. Nitekim onun halifeleri arasında yer almıştır.

Bir dönem Silopi ve çevresinde ikamet eden Şeyh Mustafa Efendi, bu bölgede ve Cizre'ye yakın köylerde irşad ve sohbet vazifesini ifa etmiştir. Cizre'de âlim ve fazıl insanlarla oturmaya özen gösteren Şeyh Efendi çoğunu ezbere bildiği Şeyh Ahmed el-Cezerî’nin divanını ve hepsini ezbere bildiği Seyyid Muhammed Kadri Haşimî'nin divanını şeyhinin dergâhında ve diğer meclislerde irad ederdi. İbadet ile dolu ömrünü 1995 yılında bir gece yarısı teheccüd namazı üzerinde tamamlamış, Cizre'de hakkın rahmetine kavuşmuştur (A. Benzer ve M. Benzer, Kişisel Görüşme, 9 Ekim 2019).

\subsection{9. Şeyh Abdülvehhab (Değer)}

1901 yılında Cizre'de dünyaya gelen Şeyh Abdülvehhab Efendi'nin babasının adı Süleyman, annesinin adı ise Sadıka'dır. Halid b. Velid'in soyundan geldikleri söylenmektedir. Seyyid Muhammed Kadri Haşimî ile beraber Cizre ve havalisinin en meşhur âlimlerinden Molla Abdurrahman Huserî'den ilim tahsilinde bulunmuştur (S. Değer, Kişisel Görüşme, 9 Ekim 2019).

Tasavvufta Şeyh Muhammed Said Seyfeddîn'e intisap etmiştir. Şeyhinin vefatından sonra tarikat pîri Şeyh Muhammed Ali Hüsameddin et-Tavîlı’nnin yanına gitmiştir. Tarikat pîrinin kendisine tasavvufî icazet vermesi üzerine Cizre'deki halifeleri arasına girmiştir. Cizre'de yaptığı tasavvufî sohbetleri ve halkı irşadı yanında ticaretle de iştigal etmiştir. İlme ve okumaya çok düşkün olan Şeyh Abdülvehhab Efendi nadide eserlerle dolu çok zengin bir kütüphane oluşturmasına rağmen vefatından sonra bu kütüphane korunamamıştır. 
Seyyid Muhammed Kadri Haşimî'ye olan sevgi ve saygısından dolayı Cizre içinde kimseye tarikat dersi vermemesine rağmen Ankara, Antakya, Gaziantep, Kütahya, Afyon ve Türkiye'nin birçok yerinde müritleri vardı. Ara sıra müritlerinin bulunduğu yerlere gider uzun müddet yanlarında kalırdı. İlim, ibadet, takva ve irşad ile dolu bir hayatı 1974 yılında noktalayan Şeyh Abdülvehhab Efendi Cizre Asri Mezarlığı'na defnedilmiştir (S. Değer ve T. Yiğit, Kişisel Görüşme, 9 Ekim 2019).

\subsubsection{0. Şeyh Şurahbil (Özalp)}

Şeyh Şurahbil Efendi 1905 yılında Cizre'de dünyaya gelmiştir. Babasının adı Abdülkadir, annesinin adı ise Celile'dir. Dönemin âlimlerinden ilim tahsilinde bulunarak çok iyi yetişen âlimler arasına girmişti. Tasavvufî icazet ve hilafetini Şah Muhammed Ali Hüsameddin'den alan Şeyh Şurahbil Efendi Cizre ve çevresinde irşad faaliyetlerinde bulunmaktaydi.

Müritleri daha çok görev yaptığı Nusaybin'de bulunan Şeyh Efendi, Şah Muhammed Ali Hüsameddin'in diğer halifeleri gibi Seyyid Muhammed Kadri Haşimî'ye olan sevgi ve hürmetlerinden dolayı daha çok Cizre dışında irşad faaliyetinde bulunurdu. Cizre içinde ise daha çok Seyyid Muhammed Kadri Hazîn Haşimî'nin sohbetinde bulunur ve onunla vakit geçirirdi. Ayrıca Seyyid Muhammed Kadri Hazîn Haşimî’nin Divanını yazan kâtiplerdendir. Şeyh Şurahbil Efendi 1995 yılında vefat ederek Cizre Asri Mezarlığı'na defnedilmiştir (R. Özalp, Kişisel Görüşme, 18 Aralık 2019).

\section{Rifâiyye Tarikatı}

Rifâiyye tarikatının pîri Seyyid Ahmed b. Seyyid Ali erRifâî olup lakabı Ebul-alemeyn'dir. Seyyid Ahmed erRifâî (512/1118) yılında Betâih bölgesinde yer alan Ümmüâbide köyünde doğdu. Babası Hz. Hüseyin neslinden olup annesi de Ebu Eyyub el-Ensârî'nin soyundandır. Küçük yaşta babasını kaybeden Seyyid Ahmed er-Rifâî'nin eğitimini zamanın meşhur mutasavvıflarından dayısı Mansur el-Betâihî üstlenmiştir (Demirci, 2013: 113; Küçük, 2015: 333).

Kur'an ve sünnete bağlı bir tasavvufi yol çizen Seyyid Ahmed er-Rifâî zahiri ilimlerde derin bir bilgiye sahip olmuştur. Zamanın Abbâsî halifesinin saygısını kazanan Ahmed er-Rifâî istikameti keramete tercih etmiştir. 578/1182 yılında Bağdat'a yakın Vasıt şehrinde vefat eden Seyyid Ahmed er-Rifâî'nin tarikatı İslam âleminin her tarafina yayılmıştır. Özellikle Ortadoğu, Anadolu ve Balkanlarda yaygın bir tarikattır (Bardakçı, 2016: 280-281; Kara, 2018: 234-235; Yiğit, 2018: 84).

\section{1. Şeyh İbrahim Rifâî (Salman)}

Şeyh İbrahim er-Rifâi (Şeyh-i din) 1880 yılında Suriye sınırları içinde yer alan ve Cizre'nin pek yakınında bulunan Derik ilçesine bağlı bir köyde doğmuştur. Babası Şeyh Ahmed, Seyyid Ahmed er-Rifầìnin neslindendir. Aynı zamanda tarikatını sürdüren ilim ve irfan sahibi meşhur bir aileye mensuptur.

Şeyh İbrahim er-Rifâî, içinde Diyarbakır ve Musul da olmak üzere bölgenin birçok şehrindeki medreselerde ilim tahsilinde bulunmuştur. En son Cizre'de Molla
Abdurrahman Huseri'den ilmi icazetini almıştır. Tasavvufî icazetini ise velayeti ile meşhur olan babası Şeyh Ahmed er-Rifâî'den almıştır. Cizre ve havalisinde pek çok müridi bulunan Şeyh İbrahim er-Rifâî Efendi'nin aileden tevarüs eden tıbb-1 Nebevi'ye vukufiyeti vardı. Cizre merkezden ve tüm bölgeden çeşitli hastalıklara dair kendisine müracaat edilirdi. Özellikle akıl hastalarının tedavisinde olumlu sonuçlar elde etmesi, şöhretinin her tarafa yayılmasına vesile olmuştur.

Kadim şehir Cizre'nin tarihini ve tarihi şahsiyetlerini çok iyi bilen Şeyh Efendi'nin bu birikiminden istifade edilememiştir. Cizre'nin ilim, irfan ve kültürüne katkısının yanında maddi problem ve hastalıklarına da çare olmaya çalışan Şeyh İbrahim er-Rifâi Efendi 1962 yilında vefat ederek Cizre'de Cafer-i Sadık Mevkiinde toprağa verilmiştir $^{21}$ (Ş. İ. Salman, Kişisel Görüşme, 3 Ocak 2020; Yaşın, 1983: 164-165).

\section{Sonuç}

Hz. Ömer döneminde fethedilen Cizre, İslam'1 kabul ettiği bu zaman diliminden itibaren yetiştirdiği ilim adamlarıyla İslam medeniyetine çok önemli katkılarda bulunmuştur. İslam âleminin değişik yerlerindeki ilim ehli için çekim merkezi haline gelen Cizre, Mevlânâ Hâlid-i Bağdâdî döneminde ve sonrasında da bu durumunu sürdürmüştür.

Tasavvuf tarihinde çok önemli bir yere sahip olmasına rağmen şehir hakkında akademik alanda yapılan araştırmaların azlığı göze çarpmaktadır. Oysaki günümüzde de ülkemizin değişik yerlerinde faaliyette bulunan birçok dergâhın silsilesi Cizre'de yetişen mutasavvıflara dayanmakta olduğu gözlemlenmektedir. Özellikle Irak, İran, Türkiye ve Ortadoğu'nun başka yerlerinde de halen çok etkin olan Mevlânâ Hâlid-i Bağdâdî'nin baş halifesi Şeyh Osman Siracüddin et-Tavîlî koluna mensup Cizreli mutasavvifların hayatları ve etki sahaları pek araştırılmamıştır. Buna Kâdirî ve Rufâi yoluna mensup mutasavviflarda eklenebilir.

Cizre'nin tarihsel süreçte birçok zahidin, mutasavvıfin yaşadığı Nakşibendiyye, Kâdirîyye ve Rufâîyye tarikatlarının yoğun bir şekilde faaliyet gösterdiği bir merkez olduğu görülmüştür. Günümüzde ise Cizre, NakşîHâlidî’liğin iki önemli koluna ev sahipliği yaptığı görülmektedir. Cizre şehrinde Rufâilliğin de varlığını sürdürmesine karşın Kâdirîliğin, artık Nakşî-Hâlidî yolunun Şeyh Osman Siracüddin et-Tavîli kolunda varlığını idame ettirdiğini görmekteyiz.

Araştırmaya konu olan Cizre mutasavvifları mensup oldukları irfani gelenekle beraber şeri ilimlerde de otorite kabul edilen kişiliklerdir. Yine tasavvuf ve tarikatlar tarihi incelenirken bu şehirdeki sûfîlerin başarılı bir şekilde manevi ve ruhanî ilimlerle zahiri ilimleri mezcettiklerine şahit olmaktayız. Son olarak belirtmemiz gerekir ki çalışmamızda tekke ve medrese geleneğini birleştiren bu sûfîler, toplumun maddi ve manevi hayatına yön vermiş Cizre'nin huzurunun ve istikrarının teminatı olmuştur. Bu erenlerin öğretilerinin zayıflamasıyla toplumda ahlaki

21 Ş İshak Salman, 1952, Cizre, 3 Ocak 2020., Yaşın, Bütün Yönleriyle Cizre, 164-165. Cizre'de hâlihazırda Şeyh İbrahim er-Rifầ̂'nin yerine geçerek Rifâi tarikatını sürdüren postnişin Şeyh İshak er-Rifâi (Salman) Efendi'dir 
çöküntü, huzursuzluk, istikrarsızlık baş göstermiş, değer yargıları sarsılmıştır .

\section{Kaynakça}

Adak, A. (2009). Seyda, Muhammed Said. Türkiye Diyanet Vakfi İslâm Ansiklopedisi. İstanbul: TDV Yayınları, 37/20-21.

Agitoğlu, N. (2015). Hadîs Usûlü Konularına Dair Bir Risale: Muhammed Nurullah Seyda'nın esSahîfetü's-Sâlise fî Usûli'l-Hadîs'i. Şırnak Üniversitesi İlahiyat Fakültesi Dergisi. 7(14) 7-22.

Ali, H. B. (2017). el-Kabâilu'l-Arabiyyeti Fî'l-Cezîreti'lFurâtiyyeti'1-'Ulyâ Fî Türkiyâ. Mecelletu Ceylu'lUlumi'l-İnsaniyyeti ve'l-Íctima'iyye. 4(37), 109125.

Avc1, C. (2010). Tağlib. Türkiye Diyanet Vakfi Ansiklopedisi. İstanbul: TDV Yayınları, 39/374375.

Bardakçı, M. N. (2016). Doğuştan Günümüze Tasavvuf ve Tarikatlar. 2. bs. İstanbul: Rağbet Yayınları.

Baytâr, A. (1993). Hilyetü'l-Beşer fî Tarîhi'l-Karni'sSâlisi Aşer. 2. bs. (Muhammed Behcet el-Baytâr. thk.) Beyrut: Dâru Sâdır.

Baz, İ. (2013). Mevlânâ Hâlid-i Bağdâdî’nin Halifelerinden Şeyh Hâlid-i Cezerî ve Basret Dergâhı. Tasavvuf ilmî ve akademik araştırma dergisi 2(32), 139-167.

Baz, İ. (2016). Seyda Muhammed Nurullah. Türkiye Diyanet Vakfi İslâm Ansiklopedisi. İstanbul: TDV Yayınlar1, Ek-2/505.

Baz, İ. (2011). Şırnak Bölgesindeki Nakşî Şeyh Aileleri ve İdil'de yaşayan Mutasavvıflar. Geçmişten Günümüze İdil Sempozyumu. M. Nesim Doru (Ed.), 1/347-361. İstanbul: Sanart Ajans,

Bingöl, A. (2008). Kulîlkên Baxê Botan. Diyarbakır: Enstiuya Kurdi ya Amedê.

Cerrahi, S. M. (2013). Istılahat-ı sofiyye fi Vatan-ı Asliyye. 2. bs. İstanbul: Kırkkandil Yayınevi.

Çıkman, Z. (ts.). İslam Alimleri Ansiklopedisi, İstanbul: İhlas Matbaacılık ve Dağıtım.

Demirci, A. (2013). Tağlib Kabilesi'nin İslâm Devleti Egemenliği Altına Alınma Süreci. Toplum Bilimleri Dergisi, 7(13), 347-361.

Demirci, M. (2013). Gönül Dünyamızı Aydınlatanlar. İstanbul: Vefa Yayınları.

Evliyalar.net. (2020). http://www.evliyalar.net/hz-seyhresid-el-dersevi/ (Erişim 09.01.2020).

Göksu, M. (2010). Muhammed Nurullah Seyda el-Cezerî (1949-1985)'nin Hayatı Şahsiyeti ve Tasavvuf Anlayışı. Uluslararası Şırnak ve Çevresi Sempozyumu. ed. M. Nesim Doru. (Ed.), 647-661. Ankara: MRK Baskı ve Tanıtım Hizmetleri.

Hamevî,Y. (1977). Mu'cemu'l-Buldân. Cilt 2, Beyrut:
Dâru Sadır.

Işık, S. (ts.). Şeyh Muhammed Said Seydâ el-Cezerî Hayatı ve Şahsiyeti, İstanbul: Obje Yayınları.

Kara, M. (2018). Tasavvuf ve Tarikatlar Tarihi. 15. bs. İstanbul: Dergâh Yayınları.

Kavak, A. (2012). Kaçar Hanedanı Döneminde (17951925) İran'da İrşad Faaliyeti Yürüten NakşbendîHâlidî Şeyhleri. Şırnak Üniversitesi İlahiyat Fakültesi Dergisi, 6(12) 93-94.

Kavak. A. (2015). Mevlânâ Hâlid-i Bağdâdî’nin Halifelerinden Şeyh Osman Siracüddin et-tavîlî (v. 1283/1866) ve Biyâre Medresesi/Tekkesi. Atatürk Üniversitesi Ilahiyat Fakültesi Dergisi (43), 260285.

Kavak. A. (2017). Müceddidî Şeyhi Mevlânâ Hâlid eLBağdâdî'nin Ortadoğu'daki Misyonu”. Ağri İslâmi İlimler Dergisi, 1(1), 1-18.

Kavak. A. (2015). Melaye Cizîrî Kürt Edebiyatının Gelişim Dönemi. Bingöl üniversitesi Yaşayan Diller Enstitüsü Dergisi. 1(2), 48-66.

Kaya, Ç. S. (1996). Gönül Sultanları ve Hak Sohbetleri. 3. bs. Ankara: Kültür Ofset.

Küçük, H. (2015). Ana Hatlarıla Tasavvuf Tarihine Giriş. 4.bs. İstanbul: Ensar Neşriyat.

Lings, M. (2017). Tasavvuf Nedir? İstanbul: Nefes Yayınları.

Müderris, A. (1983). 'Ulemâunâ fî hidmeti'l-ilmi ve'd-dîn. Bağdat: Dâru'l-Hürriyye li't-Taba'a,

Nakşibendî, Ş. M. A H. (ts.). Hüsâmî Tarikatının Bayraktarlarl, byy.

Nebhânî, Y. İ. (2001). Câmi’u Kerâmâtî Evliyâ. (İbrahim Atve Avad, thk.) Hindistan: Merkezu Ehl-i Sünnet Berkâti Rızâ.

Öngören, R. vd. (2017). tasavvuf el kitabı. 5. bs. Ankara: Grafiker Yayınları.

Özaydın, M. (2013). Birîfkân Seyyidlerinden Seyyid Nûreddîn Birîfkânî. Ekev Akademi Dergisi 16(53), 159-190.

Özdirek, R. (2012). Cumhuriyet Dönemi Cizre Bölgesi Din Âlimleri, Bilim Düşünce ve Sanatta CIZZRE Sempozyumu, ed. M. Nesim Doru. (Ed.) 223-238. İstanbul: Byy.

Özervarl1, M. S. (2005). Molla Cezerî. Türkiye Diyanet Vakfi İslâm Ansiklopedisi. İstanbul: TDV Yayınları. 30/241-243.

Risale Haber. (2020, 2 Ocak). Cizre ve İrşad faaliyetleri, Erişim adresi: https://www.risalehaber.com/cizreve-irsad-faaliyetleri-7423yy.htm

Sarı, İ. (2016). Güneydoğu Evliyalart. Antalya: Net Medya Yayıncılık.

Seydaiyye (2019, 5 Aralık). Seydaiyye Cizre'nin Nakşî Hâlidi Seydai Postnişinleri Erişim adresi: http://seydaiyye.tk/component/content/article/319.h $\underline{\mathrm{tml}}$ 
Şeşen, R. (1993). “Cezîre”. Türkiye Diyanet Vakfi İslâm Ansiklopedisi. İstanbul: TDV Yayınlar1, 7/509-510.

Tunçer, O. C. (2006). Mardin- Cizre Kırmızı Medrese. Vakıflar Dergisi. (10), 425-449.

Türer, O. (2018). Ana Hatlarlyla Tasavvuf Tarihi. 5. bs. İstanbul: Ataç Yayınları.

Uludağ, S. (2016). Tasavvuf Terimleri Sözlüğü. 2. bs. İstanbul: Kabalcı Yayıncılık.

Vâkıdî, M.V. (1417/1996). Tarîh Futûhi'l-Cezîreti ve'lHâbûri ve Diyarbekr ve'l-Irak. (Abdülaziz Feyyad Harfûş thk.) Şam: Dâru'l-Beşâir Li’t-Tabâ'ati ve'nNeşri ve't-Tevzi'. yahyamunis.blogspot.com (2019 5 Aralık), Erişim adresi: http://yahyamunis.blogspot.com/2013/05/munis-eldersevi-ailesi.html

Yaşın, A. (1983). Bütün Yönleriyle Cizre. İstanbul: Yücel Matbaacilik.

Yilmaz, H. K. (2009). Anahatlarlyla Tasavvuf ve Tarikatlar, 12. bs. İstanbul: Ensar Neşriyat.

Yiğit, Mesut. (2018). Yusuf en-Nebhânî ve Şiirindeki Tasavvufî Unsurlar. Doktora Tezi. Atatürk Üniversitesi Sosyal Bilimler Enstitüsü, Erzurum. 